\title{
Rapid diagnosis of candidaemia by real-time PCR detection of Candida DNA in blood samples
}

\begin{abstract}
Correspondence
Nele Wellinghausen

nele.wellinghausen@

labor-gaertner.de
\end{abstract}

Received 9 November 2008

Accepted 15 April 2009

\author{
Nele Wellinghausen, ${ }^{1,2}$ Dunja Siegel, ${ }^{1}$ Juliane Winter ${ }^{1} \dagger$ \\ and Susanne Gebert ${ }^{1} \dagger$ \\ ${ }^{1}$ Institute of Medical Microbiology and Hygiene, University Hospital of Ulm, Ulm, Germany
${ }^{2}$ Dr Gaertner \& Partner Laboratories, Ravensburg, Germany
}

This study prospectively evaluated an 18S rRNA gene-targeted real-time PCR approach in comparison with standard blood culture (BC) diagnostics for rapid diagnosis of candidaemia in a large study population of 384 patients, including 902 whole blood samples from 468 infectious episodes (IEs) of 329 adults and 55 children with haematological malignancies and various forms of immunodeficiency, and intensive care unit patients. Seven out of eight BC-proven cases ( $87.5 \%)$ of candidaemia and seven out of twelve BC-positive samples (58.3\%) were positive by the Candida-specific PCR. A positive PCR result was also obtained for 28/460 BC-negative samples from IEs, including 8 patients with culture-confirmed Candida infection at primary sterile body sites. Of the PCR-positive, culture-negative patients, more than $50 \%$ received systemic antifungal therapy. In 432/460 BC-negative IEs, the Candida specific-PCR was negative, resulting in a negative predictive value of $99.8 \%$. In conclusion, the Candida specific-PCR approach facilitates rapid detection of Candida DNA in blood samples of patients at risk of candidaemia within a few hours. Although standard BC diagnostics appear to remain indispensable for the detection of all cases of candidaemia, this PCR assay allowed the detection of candidaemia at a mean of 3 days earlier than BC diagnostics. Thus, it enables earlier antifungal therapy for patients with suspected candidaemia and may prevent further complications.

\section{INTRODUCTION}

Candidaemia accounts for up to $10 \%$ of bloodstream infections and is associated with an exceptionally high mortality rate, reaching up to $50 \%$ in intensive care unit (ICU) patients (Engel et al., 2007; Laupland et al., 2004; Wisplinghoff et al., 2004). Rapid initiation of antifungal therapy is crucial for the survival of patients (Kumar et al., 2006). At present, blood cultures (BCs) incubated in automated BC systems remain the 'gold standard' for diagnosing candidaemia. However, it usually takes 3-5 days of incubation until growth of Candida spp. is detected.

Detection of fungal DNA in blood samples, without prior cultivation, is a promising approach for the rapid detection of Candida spp. in patients with suspected candidaemia. Fungalspecific PCR assays, mostly targeting regions of the $5.8 \mathrm{~S}, 18 \mathrm{~S}$ or $28 \mathrm{~S}$ rRNA genes, or internal transcribed spacer regions, have been evaluated for use with serum or blood samples of various patient groups, such as neonates, patients with haematological malignancies or ICU patients (Ahmad et al., 2002; Alam et al., 2007; Dunyach et al., 2008; Innings et al.,

†These authors contributed equally to this work.

Abbreviations: $\mathrm{BC}$, blood culture; $\mathrm{C}_{t}$, threshold cycle; $\mathrm{ICU}$, intensive care unit; IE, infectious episode.
2007; Klingspor \& Jalal, 2006; Maaroufi et al., 2003; MoreiraOliveira et al., 2005; Tirodker et al., 2003). Recently, a new preanalytical tool for PCR analysis of blood samples, MolYsis (Molzym), has been brought to market. The principle of MolYsis involves lysis of human blood cells prior to degradation of bacterial and fungal cell walls, allowing digestion of human DNA by DNase and thus enrichment of pathogen DNA (Horz et al., 2008). In addition, PCR inhibitors can be removed efficiently by the MolYsis procedure. In a recent study, the use of MolYsis pre-incubation showed promising results regarding the rapid detection of Candida species in BC samples (Gebert et al., 2008).

In the present study, we prospectively evaluated a real-time PCR approach, in conjunction with sample preparation using MolYsis, for rapid diagnosis of candidaemia in a large study population of 384 patients at risk of candidaemia, including children and adults with haematological malignancies and various forms of severe immunodeficiency, and ICU patients.

\section{METHODS}

Study population. The study was performed at three hospitals belonging to the University of Ulm (Ulm, Germany) in the 
Departments of Medicine, Paediatrics and Surgical Intensive Care from 7 December 2007 to 31 August 2008. The criteria for inclusion of patients in the study were as follows: ICU patients with systemic inflammatory response syndrome or sepsis (Bone et al., 1992), haematology/oncology patients with fever $>38.5^{\circ} \mathrm{C}$ in neutropenia $\left(<1 \times 10^{9}\right.$ neutrophils $\left.1^{-1}\right)$ or patients with other forms of hereditary or acquired immunodeficiency and fever $>38.5{ }^{\circ} \mathrm{C}$. Within one infectious episode (IE), subsequent samples were included only when obtained within 7 days of sampling of the initial sample. A patient was eligible for the study a second time if the new IE occurred more than 4 weeks after the initial inclusion of the patient into the study and if a BC-confirmed infection with an identical species had been ruled out. The study was approved by the ethics committee of the University of Ulm (reference no. 175/07) and informed consent was obtained from all patients or parents of patients included in the study. For ICU patients, post-hoc informed consent was obtained.

Blood samples. Blood samples for PCR were collected in $5 \mathrm{ml}$ (adults), $2.5 \mathrm{ml}$ or $1.4 \mathrm{ml}$ citrate tubes (children) (Sarstedt). Prior to the start of the study, the use of EDTA and citrate anti-coagulated blood was compared. In three independent experiments, we found a slightly higher sensitivity of the PCR assays in citrate anti-coagulated blood in comparison with EDTA anti-coagulated blood. The blood collection team was advised to obtain a citrate blood sample for PCR and a $20 \mathrm{ml}$ blood sample for inoculation of a pair of aerobic and anaerobic BACTEC Plus/F BC bottles (BACTEC PED bottles in children) from the same venepuncture or catheter blood sample, respectively. The blood sample for PCR analysis was fixed to the parallel BC to allow definite allocation. Blood samples and BCs were transported to the laboratory within $16 \mathrm{~h}$. BCs were incubated in an automated BACTEC 9240 system for 7 days and cultured Candida isolates were identified by API ID32C (bioMérieux). Blood samples for PCR analysis were stored at $2-8{ }^{\circ} \mathrm{C}$ until DNA isolation.

DNA isolation. Isolation of DNA was performed twice daily from Monday to Friday, using a MolYsis Complete5 kit (Molzym). The principle of the MolYsis Complete kit involves lysis of human blood cells prior to degradation of bacterial and fungal cell walls, allowing enrichment of pathogen DNA (Gebert et al., 2008; Horz et al., 2008). The kit was used as indicated by the manufacturer with the following adaptations: the volumes of the CM and DB1 buffers were adapted depending on the blood sample volume: $250 \mu$ each buffer was added to $1 \mathrm{ml}$ blood samples, $800 \mu \mathrm{l}$ each to $2 \mathrm{ml}$ blood samples, and $2 \mathrm{ml}$ each to $5 \mathrm{ml}$ blood samples. Before incubation of the samples with BugLysis solution $\left(37^{\circ} \mathrm{C}, 30 \mathrm{~min}\right.$; contained in the kit), $1.4 \mu \mathrm{l} \beta$ mercaptoethanol was added. The isolated DNA was eluted in $100 \mu \mathrm{l}$ EB buffer and stored at $-20{ }^{\circ} \mathrm{C}$ until use. With each kit, a PCR-grade water control for DNA isolation was used. DNA isolation was carried out under a HEPA-filtered PCR working bench, which was decontaminated daily by UV radiation and strictly separated from PCR working places.

PCR analysis. For detection of Candida species, a Candida-specific 18S rRNA gene-targeted PCR was run on a LightCycler 1.0 instrument. The amplification mixture consisted of $0.25 \mu \mathrm{M}$ primer FungL543 and $0.75 \mu \mathrm{M}$ primer FungL1046R (Einsele et al., 1997), $0.15 \mu \mathrm{M}$ probe Can-LC (5'-CCAAGGACGTTTTCATTAATCAAGA$\left.3^{\prime}\right), 0.15 \mu \mathrm{M}$ probe Can-FL (5'-LCRed640-CGAAAGTTAGGGGATCGAAGATG-3') (Klingspor \& Jalal, 2006), $4 \mu$ l LightCycler FastStart DNA Master ${ }^{\text {PLUS }}$ HybProbe-Mix and $5 \mu$ template DNA, in a total volume of $20 \mu \mathrm{l}$. The primer FungL1046R was used at a higher concentration than the forward primer in order to decrease an observed 'hook' effect seen with equimolar concentrations. Samples were amplified with the following program: initial denaturation at $95{ }^{\circ} \mathrm{C}$ for $10 \mathrm{~min}$, followed by 50 cycles of denaturation for $10 \mathrm{~s}$ at $95{ }^{\circ} \mathrm{C}$, annealing for $10 \mathrm{~s}$ at $58{ }^{\circ} \mathrm{C}$ and elongation for $20 \mathrm{~s}$ at $72{ }^{\circ} \mathrm{C}$, followed by melting-curve analysis. In every PCR run, a negative control (PCR-grade water) and a positive control (Candida albicans

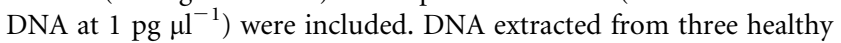
volunteers was investigated before initiation of the study and was negative in the PCR assay (data not shown).

The sensitivity and specificity of the PCR probes have been determined elsewhere (Klingspor \& Jalal, 2006). We also investigated DNA samples $\left(10 \mathrm{pg} \mu \mathrm{l}^{-1}\right)$ of each of the following fungal isolates with the PCR assay used in this study and all isolates resulted in correct positive and negative results: C. albicans (ATCC 14053), Candida ciferrii [control strain from the World Health Organization Collaborating Center for Quality Assurance and Standardization in Laboratory Medicine (INSTAND)], Candida dubliniensis (control strain 01-2004; INSTAND), Candida famata (DSM 3428), Candida glabrata (ATCC 90030), Candida kefyr (DSM 11954), Candida krusei (ATCC 90878), Candida lusitaniae (clinical isolate), Candida parapsilosis (ATCC 22019), Candida rugosa (DSM 70761), Candida tropicalis (clinical isolate), Candida valida (control strain from INSTAND), Absidia corymbifera (clinical isolate), Aspergillus fumigatus, Aspergillus flavus, Aspergillus terreus, Aspergillus niger (all clinical isolates), Cryptococcus neoformans (ATCC 62066), Saccharomyces cerevisiae (ATCC 9763), Scedosporium apiospermum (clinical isolate), and Trichosporon inkin (clinical isolate). A BLAST analysis revealed $100 \%$ identity of the combined probe sequence with the environmental fungi Macrorhabdus ornithogaster (GenBank accession no. AF350243), Pichia anomala (EF550479), Saccharomyces cerevisiae (EF153844), Saccharomycopsis microspora (EU057528) and Zygosaccharomyces lentus (Y16814). The limit of detection was repeatedly determined as $10 \mathrm{fg}$ C. glabrata DNA $\mu \mathrm{l}^{-1}$, i.e. $50 \mathrm{fg}$ per PCR, in sterile water. In addition, the sensitivity of the assay in spiked citrate blood of healthy volunteers was investigated in three repeated experiments. A detection limit of 1 c.f.u. per PCR or 3 c.f.u. (ml blood $)^{-1}$ was determined in all three experiments.

\section{RESULTS AND DISCUSSION}

\section{Study population}

A total of 902 blood samples from 384 patients ( 329 adults and 55 children $<18$ years) were included in the study. The samples were obtained in 468 IEs, including 379 from adults and 89 from children. A single blood sample was obtained in 197 IEs, two in 126 IEs, three in 134 IEs and four or more in 11 IEs.

\section{PCR results of $B C$-positive samples}

Candida species were cultured in 12 of the 902 BCs, comprising 7 isolates of C. albicans, 1 C. glabrata isolate and 4 isolates of $C$. tropicalis. Candida DNA was detected by PCR in 7 of the 12 corresponding blood samples (Table 1). Separate analysis of adult ICU patients and patients with severe immunosuppression (haematology/ oncology patients and patients with hereditary immunodeficiency, severe immunosuppressive therapy or AIDS) revealed a higher sensitivity of the PCR assay in samples from ICU patients (Table 2). It can be speculated that this was caused by a higher load of fungal DNA in ICU patients, indicated by lower threshold cycle $\left(C_{\mathrm{t}}\right)$ values of PCRpositive samples (Table 3) or by an inhibitory effect of chemotherapeutic therapy of haematological patients on the fungal DNA in blood. Nevertheless, due to the small 
Table 1. BC and PCR results

\begin{tabular}{|c|c|c|c|c|c|c|c|c|}
\hline Sample & $\begin{array}{l}\text { BC result for } \\
\text { Candida spp. }\end{array}$ & PCR positive & PCR negative & Total & $\begin{array}{c}\text { Sensitivity } \\
(\%)\end{array}$ & $\begin{array}{c}\text { Specificity } \\
(\%)\end{array}$ & $\begin{array}{l}\text { PPV } \\
(\%)\end{array}$ & $\begin{array}{l}\text { NPV } \\
(\%)\end{array}$ \\
\hline \multirow[t]{2}{*}{ Blood/BC $(n=902)$} & Positive & 7 & 5 & 12 & 58.3 & 96.2 & 17.0 & 99.4 \\
\hline & Negative & 34 & 856 & 890 & & & & \\
\hline \multirow[t]{2}{*}{ IEs $(n=468)$} & Positive & 7 & 1 & 8 & 87.5 & 94.0 & 20.0 & 99.8 \\
\hline & Negative & 28 & 432 & 460 & & & & \\
\hline
\end{tabular}

PPV, Positive predictive value; NPV, negative predictive value.

Table 2. $B C$ and PCR results in samples from ICU patients and patients with immunosuppression

\begin{tabular}{|c|c|c|c|c|c|c|c|c|}
\hline Blood/BC sample & $\begin{array}{l}\mathrm{BC} \text { result for } \\
\text { Candida spp. }\end{array}$ & $\begin{array}{c}\text { PCR } \\
\text { positive }\end{array}$ & $\begin{array}{c}\text { PCR } \\
\text { negative }\end{array}$ & Total & $\begin{array}{c}\text { Sensitivity } \\
(\%)\end{array}$ & $\begin{array}{c}\text { Specificity } \\
(\%)\end{array}$ & $\begin{array}{l}\text { PPV } \\
(\%)\end{array}$ & $\begin{array}{l}\text { NPV } \\
(\%)\end{array}$ \\
\hline \multirow[t]{2}{*}{ ICU patients $(n=420)$} & Positive & 5 & 0 & 5 & 100 & 97.1 & 29.4 & 100 \\
\hline & Negative & 12 & 403 & 415 & & & & \\
\hline \multirow[t]{2}{*}{ Patients with immunosuppression $(n=487)$} & Positive & 2 & 5 & 7 & 28.6 & 95.4 & 8.3 & 98.9 \\
\hline & Negative & 22 & 458 & 480 & & & & \\
\hline
\end{tabular}

PPV, Positive predictive value; NPV, negative predictive value.

Table 3. Characteristics of BC- and PCR-positive patients

\begin{tabular}{|c|c|c|c|c|c|c|c|c|c|c|c|}
\hline $\begin{array}{l}\text { Patient } \\
\text { no. }\end{array}$ & $\begin{array}{c}\text { Age } \\
\text { (years) }\end{array}$ & Ward & Underlying disease & $\mathrm{BC}$ result & $\begin{array}{c}\text { No. } \\
\text { positive } \\
\text { BC/no. } \\
\text { sampled }\end{array}$ & $\begin{array}{l}\text { BC time } \\
\text { to } \\
\text { positivity } \\
(h)^{\star}\end{array}$ & $\begin{array}{c}\text { No. PCR- } \\
\text { positive } \\
\text { samples/ } \\
\text { no. } \\
\text { sampled }\end{array}$ & $\begin{array}{l}C_{\mathrm{t}} \text { value } \\
\text { of PCR- } \\
\text { positive } \\
\text { samples }\end{array}$ & $\begin{array}{c}\text { No. } \\
\text { PCR- } \\
\text { and BC- } \\
\text { positive } \\
\text { samples }\end{array}$ & $\begin{array}{c}\text { Sampling } \\
\text { days } \dagger\end{array}$ & $\begin{array}{c}\text { Antifungal } \\
\text { therapy } \ddagger\end{array}$ \\
\hline 137 & 72 & Hema & $\begin{array}{l}\text { Adenocarcinoma } \\
\text { from an unknown } \\
\text { primary tumour }\end{array}$ & C. albicans & $1 / 1$ & 57 & $1 / 1$ & 29 & 1 & Day 1 & $\begin{array}{l}\text { Day 4, } \\
\text { FLU } 200\end{array}$ \\
\hline 176 & 59 & Hema & Malignant thymoma & C. tropicalis & $2 / 4$ & $18 / 18$ & $1 / 4$ & 36 & 0 & $\begin{array}{l}\text { Day } 1,4, \\
7,8\end{array}$ & $\begin{array}{l}\text { Day 9, } \\
\text { FLU } 400\end{array}$ \\
\hline 199 & 65 & Hema & $\begin{array}{l}\text { Metastatic breast } \\
\text { cancer, polythro- } \\
\text { mbotic disease }\end{array}$ & C. glabrata & $1 / 2$ & 83 & $1 / 2$ & 34 & 0 & Day 1 & $\begin{array}{l}\text { Day } 3, \\
\text { VORI } 800\end{array}$ \\
\hline 355 & 56 & ICU & Gastric cancer & C. albicans & $1 / 3$ & 72 & $3 / 3$ & $29 / 32 / 36$ & 1 & Day 1,2 & $\begin{array}{l}\text { Day } 4, \\
\text { CASPO }\end{array}$ \\
\hline 359 & 46 & ICU & $\begin{array}{l}\text { Small bowel ischaemia, } \\
\text { aortic thrombosis }\end{array}$ & C. albicans & $3 / 3$ & $40-48$ & $3 / 3$ & $32 / 34 / 36$ & 3 & Day 1 & $\begin{array}{l}\text { Day 3, } \\
\text { VORI } 800\end{array}$ \\
\hline 422 & 66 & ICU & $\begin{array}{l}\text { Near-drowning, } \\
\text { mechanical ileus }\end{array}$ & C. albicans & $1 / 3$ & 124 & $2 / 3$ & $32 / 32$ & 1 & Day 1,3 & $\begin{array}{l}\text { Day 3, FLU } \\
400\end{array}$ \\
\hline 845 & 42 & Hema & $\begin{array}{l}\text { Acute myeloic } \\
\text { leukaemia }\end{array}$ & C. tropicalis & $2 / 2$ & $25 / 38$ & $1 / 2$ & 37 & 1 & Day 1 & $\begin{array}{l}\text { Day 2, } \\
\text { CASPO }\end{array}$ \\
\hline 411 & 48 & Hema & $\begin{array}{l}\text { Acute myeloic } \\
\text { leukaemia }\end{array}$ & C. albicans & $1 / 1$ & 74 & $0 / 1$ & - & 0 & Day 1 & $\begin{array}{l}\text { Day 6, } \\
\text { CASPO }\end{array}$ \\
\hline
\end{tabular}

Hema, Haematology/oncology.

${ }^{*}$ Incubation time until positive signal was obtained using the BACTEC system.

$\dagger$ Days at which blood samples were taken for PCR and BC (day $1=$ first sample).

$\ddagger$ Day of initiation (day $1=$ day of sampling of first sample) and antifungal treatment used: FLU 200, $200 \mathrm{mg}$ fluconazole day ${ }^{-1}$; FLU $400,400 \mathrm{mg}$ fluconazole day ${ }^{-1}$; VORI 800, $800 \mathrm{mg}$ voriconazole day ${ }^{-1}$; CASPO, caspofungin. 
Table 4. Characteristics of BC-negative, PCR-positive patients

\begin{tabular}{|c|c|c|c|c|c|c|c|}
\hline $\begin{array}{l}\text { Patient } \\
\text { no. }\end{array}$ & $\begin{array}{c}\text { Age } \\
\text { (years) }\end{array}$ & Ward & Underlying disease & $\begin{array}{c}\text { No. PCR positive } \\
\text { samples/no. sampled }\end{array}$ & $\begin{array}{l}C_{\mathrm{t}} \text { value of } \mathrm{PCR} \\
\text { positive samples }\end{array}$ & $\begin{array}{l}\text { Antifungal therapy } \\
\text { or prophylaxis* }\end{array}$ & $\begin{array}{l}\text { Positive Candida spp. culture } \\
\text { in other specimens } \dagger\end{array}$ \\
\hline 43 & 48 & ICU & Vertebral osteomyelitis & $1 / 3$ & 30 & None & $\begin{array}{l}+++ \text { C. albicans, bronchial secretions } \\
\quad(\text { day }-1 \text { and } 0)\end{array}$ \\
\hline 76 & 49 & ICU & AIDS, Pneumocystis jirovecipneumonia & $2 / 2$ & $32 / 32$ & None & +++ non-albicans Candida, CVC $($ day +1$)$ \\
\hline 98 & 65 & ICU & Community-acquired pneumonia & $1 / 3$ & 35 & $200 \mathrm{mg}$ fluconazole per day & $\begin{array}{l}+ \text { C. albicans in tracheal aspirate (day } 0) \\
++ \text { C. albicans in bronchial secretion } \\
\quad(\text { day }-3 \text { and }+2)\end{array}$ \\
\hline 183 & 47 & ICU & Oesophagus perforation & $1 / 3$ & 35 & None & $\begin{array}{l}+ \text { C. albicans in tracheal aspirate (day } \\
\quad+1) ;+ \text { non-albicans Candida in } \\
\text { pleural effusion }(\text { day }+2)\end{array}$ \\
\hline 207 & 62 & ICU & Aortic aneurysm & $1 / 3$ & 37 & None & $\begin{array}{l}+ \text { C. albicans in bronchial secretion and } \\
\text { tracheal aspirate }(\text { day }-3)\end{array}$ \\
\hline 221 & 60 & Hema & Multiple myeloma & $1 / 3$ & 33 & $3 \mathrm{~g}$ amphotericin OS per day & ++ C. albicans in stool $($ day +3$)$ \\
\hline 304 & 38 & ICU & Thoracic spine spondylodesis & $1 / 3$ & 34 & None & $\begin{array}{l}++C . \text { albicans in bronchial secretion } \\
\text { and tracheal aspirate }(\text { day }+2)\end{array}$ \\
\hline 327 & 46 & ICU & Stomach perforation & $1 / 3$ & 37 & None & $\begin{array}{l}+++ \text { C. albicans in intra-abdominal } \\
\text { swab }(\text { day }-1 \text { and }+2)\end{array}$ \\
\hline 341 & 64 & ICU & Coronary artery disease & $1 / 3$ & 33 & None & $+C$. non-albicans in sputum $($ day -1$)$ \\
\hline $834 \ddagger$ & 65 & Hema & $\begin{array}{l}\text { Metastatic breast cancer, poly- } \\
\text { thrombotic disease }\end{array}$ & $1 / 1$ & 34 & $600 \mathrm{mg}$ posaconazole per day & $\begin{array}{l}\text { C. glabrata in BC }(\text { day }-21) ;++ \text { non- } \\
\text { albicans Candida in sputum (day } 0)\end{array}$ \\
\hline 8 & 45 & Hema & Acute myeloic leukaemia & $1 / 5$ & 36 & $3 \mathrm{~g}$ amphotericin OS per day & No \\
\hline 29 & 7 & Hema & Acute lymphatic leukaemia & $1 / 2$ & 34 & None & No \\
\hline 44 & 23 & Hema & Acute lymphatic leukaemia & $1 / 2$ & 34 & $600 \mathrm{mg}$ posaconazole per day & No \\
\hline 65 & 62 & Hema & Myelodysplastic syndrome & $1 / 2$ & 35 & $800 \mathrm{mg}$ posaconazole per day & No \\
\hline 66 & 43 & Hema & Non-Hodgkin lymphoma & $1 / 2$ & 37 & $600 \mathrm{mg}$ posaconazole per day & No \\
\hline 100 & 51 & Hema & Acute myeloic leukaemia & $1 / 3$ & 37 & $3 \mathrm{~g}$ amphotericin OS per day & No \\
\hline 162 & 72 & Hema & Multiple myeloma & $1 / 1$ & 36 & $100 \mathrm{mg}$ fluconazole per day & No \\
\hline 165 & 59 & Hema & Osteomyelofibrosis & $1 / 1$ & 37 & $600 \mathrm{mg}$ posaconazole per day & No \\
\hline 170 & 75 & Hema & Non-Hodgkin lymphoma & $1 / 3$ & 35 & None & No \\
\hline 181 & 39 & Hema & Mantle cell lymphoma & $1 / 1$ & 35 & $100 \mathrm{mg}$ fluconazole per day & No \\
\hline 220 & 40 & ICU & Sarcoidosis & $1 / 3$ & 36 & None & No \\
\hline 235 & 79 & ICU & $\begin{array}{l}\text { Coronary artery disease, preterminal } \\
\text { renal insufficiency }\end{array}$ & $1 / 2$ & 36 & None & No \\
\hline 293 & 71 & Hema & Acute myeloic leukaemia & $1 / 2$ & 36 & $400 \mathrm{mg}$ voriconazole per day & No \\
\hline 302 & 55 & Hema & Chronic lymphatic leukaemia & $1 / 1$ & 34 & $600 \mathrm{mg}$ posaconazole per day & No \\
\hline 316 & 5 & Hema & Burkitt lymphoma & $1 / 2$ & 37 & None & No \\
\hline 356 & 0.5 & Hema & Nephroblastoma & $1 / 3$ & 37 & None & No \\
\hline 836 & 70 & Hema & Acute myeloic leukaemia & $1 / 1$ & 34 & $600 \mathrm{mg}$ voriconazole per day & No \\
\hline 837 & 28 & Hema & Acute myeloic leukaemia & $1 / 3$ & 37 & $600 \mathrm{mg}$ posaconazole per day & No \\
\hline
\end{tabular}

CVC, Central vascular catheter; Hema, haematology/oncology; OS, oral suspension.

*Actual therapy or prophylaxis at day of blood sampling for PCR. In all patients the antifungals were already given for a minimum of 2 days preceding blood sampling.

†Day of positive culture result with regard to the sampling day of the PCR-positive blood sample is given in parentheses; day $0=$ day of blood sampling.

¥Second IE of patient no. 199 (Table 2), 40 days after first inclusion into the study. 
number of positive samples, the data are still preliminary. In all BC-positive, but PCR-negative samples, PCR inhibition was excluded by spiking of the DNA sample with C. albicans DNA $\left(1 \mathrm{pg} \mu \mathrm{l}^{-1}\right)$.

The 12 positive BCs were sampled from 8 patients (Table 3). Defining a PCR-positive patient as a patient with a positive PCR result in at least one blood sample of all samples obtained within the same IE, seven of the eight BC-positive patients were positive in the Candida specificPCR (Tables 1 and 3), corresponding to an IE-related sensitivity of $87.5 \%$. This sensitivity is in accordance with published studies reporting sensitivities of 72.1 to $100 \%$ (Ahmad et al., 2002; Alam et al., 2007; Dunyach et al., 2008; Innings et al., 2007; Klingspor \& Jalal, 2006; Maaroufi et al., 2003; Moreira-Oliveira et al., 2005; Tirodker et al., 2003). In contrast to former studies, however, we investigated a large, heterogeneous study population at risk of candidaemia, consisting of both patients with immunodeficiency and patients treated in the ICU, in order to evaluate the PCR approach regarding its hospital-wide applicability in a tertiary-care university hospital.

In patients with more than one blood sample investigated, the samples were taken within 1-7 days (Table 3). Remarkably, in patient 176, the PCR was already positive in the first sample (day 1), but the candidaemia was first detected by $\mathrm{BC}$ in the day 7 sample. In the other patients, $\mathrm{BC}$ and PCR were positive in samples obtained on the same day. After receiving the positive $\mathrm{BC}$ result, all patients were treated with systemic antifungals. Whilst the BCs were positive after a mean of $60 \mathrm{~h}$ of incubation (Table 3), a positive PCR result could be obtained within $4 \mathrm{~h}$ of arrival of the sample in the laboratory and may thus enable significantly earlier initiation of antifungal therapy.

\section{PCR results of BC-negative samples}

A positive Candida specific-PCR result was obtained in 34/ 890 BC-negative samples and in 28/460 IEs, respectively (Tables 1 and 4). PCR was positive in $2 / 2$ samples in a patient with culture-confirmed central venous catheter infection with $C$. albicans (Table 4). In another seven patients, Candida spp. was cultured in specimens from a primary sterile body site \pm 3 days from the day of blood sampling (Table 4). Therefore, in these patients, invasive Candida infection associated with candidaemia is very likely. Two further patients were colonized with Candida spp. in sputum or stool (Table 4). Of the remaining 18 culture-negative but PCR-positive patients, 10 (55.6\%) were receiving systemic antifungal therapy and $2(11.1 \%)$ were treated with amphotericin oral suspension on the day of blood sampling (Table 4). Unfortunately, Candida colonization of the patients was not systematically recorded in this study, but due to their underlying disease and/or actual medical treatment, all patients were at increased risk of systemic Candida infection. Positive Candida specificPCR results in BC-negative patients with suspected invasive
Candida infection have also been reported sporadically in other studies (Ahmad et al., 2002; Alam et al., 2007; Dunyach et al., 2008; Klingspor \& Jalal, 2006; Maaroufi et al., 2003). Although growth of Candida spp. in BC is considered the 'gold standard' for diagnosis of candidaemia, the sensitivity of BC is limited (Bretagne \& Costa, 2006) and may be further decreased by prophylactic administration of antifungal agents. We assume that the positive PCR in BC-negative patients most likely reflects the presence of at least temporary candidaemia. However, a false-positive PCR result cannot be fully excluded.

In conclusion, the Candida specific-PCR approach presented here enables rapid detection of Candida DNA in blood samples of patients at risk of candidaemia. Although standard $\mathrm{BC}$ diagnostics appear to remain indispensable for the detection of all cases of candidaemia, this PCR assay allowed detection of candidaemia at a mean of 3 days earlier than BC diagnostics and detected Candida DNA in the blood samples of patients with culture-documented but BC-negative Candida infection. Although identification of the Candida species is important for appropriate treatment and a reduction of the risk of development of resistance, it is critical to get a rapid result of candidaemia to achieve an optimal outcome for the patient. The total assay time of $4 \mathrm{~h}$, including isolation of DNA and PCR analysis, even allows reporting of the result on the same day that the sample is taken. Thus, it enables earlier antifungal therapy of the patients and may prevent further complications of candidaemia such as dissemination to other organs. In addition, in BC-negative patients, PCR may also be used as an adjunctive tool for exclusion of candidaemia in patients at high risk of systemic Candida infection, especially those receiving antifungal agents at a prophylactic dosage.

\section{ACKNOWLEDGEMENTS}

We thank Martin Bommer, Donald Bunjes, Hartmut Döhner, Manfred Hönig, Peter Kern, Wolfgang Lindner, Nikolaus Marx, Ansgar Schulz, Stephan Stilgenbauer and Heidemarie Suger-Wiedeck for excellent cooperation regarding clinical implementation of the study. This work was supported by the Bundesministerium für Wirtschaft und Technologie (ProInno II).

\section{REFERENCES}

Ahmad, S., Khan, Z., Mustafa, A. S. \& Khan, Z. U. (2002). Seminested PCR for diagnosis of candidemia: comparison with culture, antigen detection, and biochemical methods for species identification. J Clin Microbiol 40, 2483-2489.

Alam, F. F., Mustafa, A. S. \& Khan, Z. U. (2007). Comparative evaluation of $(1,3)-\beta$-D-glucan, mannan and anti-mannan antibodies, and Candida species-specific snPCR in patients with candidemia. BMC Infect Dis 7, 103-111.

Bone, R. C., Balk, R. A., Cerra, F. B., Dellinger, R. P., Fein, A. M., Knaus, W. A., Schein, R. M. \& Sibbald, W. J. (1992). Definitions for sepsis and organ failure and guidelines for the use of innovative therapies in sepsis. The ACCP/SCCM Consensus Conference 
Committee. American College of Chest Physicians/Society of Critical Care Medicine. Chest 101, 1644-1655.

Bretagne, S. \& Costa, J. M. (2006). Towards a nucleic acid-based diagnosis in clinical parasitology and mycology. Clin Chim Acta 363, 221-228.

Dunyach, C., Bertout, S., Phelipeau, C., Drakulovski, P., Reynes, J. \& Mallie, M. (2008). Detection and identification of Candida spp. in human serum by LightCycler real-time polymerase chain reaction. Diagn Microbiol Infect Dis 60, 263-271.

Einsele, H., Hebart, H., Roller, G., Loffler, J., Rothenhofer, I., Muller, C. A., Bowden, R. A., van Burik, J., Engelhard, D. \& other authors (1997). Detection and identification of fungal pathogens in blood by using molecular probes. J Clin Microbiol 35, 1353-1360.

Engel, C., Brunkhorst, F. M., Bone, H. G., Brunkhorst, R., Gerlach, H., Grond, S., Gruendling, M., Huhle, G., Jaschinski, U. \& other authors (2007). Epidemiology of sepsis in Germany: results from a national prospective multicenter study. Intensive Care Med 33, 606-618.

Gebert, S., Siegel, D. \& Wellinghausen, N. (2008). Rapid detection of pathogens in blood culture bottles by real-time PCR in conjunction with the pre-analytic tool MolYsis. J Infect 57, 307-316.

Horz, H. P., Scheer, S., Huenger, F., Vianna, M. E. \& Conrads, G. (2008). Selective isolation of bacterial DNA from human clinical specimens. J Microbiol Methods 72, 98-102.

Innings, A., Ullberg, M., Johansson, A., Rubin, C. J., Noreus, N., Isaksson, M. \& Herrmann, B. (2007). Multiplex real-time PCR targeting the RNase P RNA gene for detection and identification of Candida species in blood. J Clin Microbiol 45, 874-880.
Klingspor, L. \& Jalal, S. (2006). Molecular detection and identification of Candida and Aspergillus spp. from clinical samples using real-time PCR. Clin Microbiol Infect 12, 745-753.

Kumar, A., Roberts, D., Wood, K. E., Light, B., Parrillo, J. E., Sharma, S., Suppes, R., Feinstein, D., Zanotti, S. \& other authors (2006). Duration of hypotension before initiation of effective antimicrobial therapy is the critical determinant of survival in human septic shock. Crit Care Med 34, 1589-1596.

Laupland, K. B., Kirkpatrick, A. W., Church, D. L., Ross, T. \& Gregson, D. B. (2004). Intensive-care-unit-acquired bloodstream infections in a regional critically ill population. J Hosp Infect 58, 137-145.

Maaroufi, Y., Heymans, C., De Bruyne, J. M., Duchateau, V., Rodrigues-Villalobos, H., Aoun, M. \& Crokaert, F. (2003). Rapid detection of Candida albicans in clinical blood samples by using a TaqMan-based PCR assay. J Clin Microbiol 41, 3293-3298.

Moreira-Oliveira, M. S., Mikami, Y., Miyaji, M., Imai, T., Schreiber, A. Z. \& Moretti, M. L. (2005). Diagnosis of candidemia by polymerase chain reaction and blood culture: prospective study in a high-risk population and identification of variables associated with development of candidemia. Eur J Clin Microbiol Infect Dis 24, 721-726.

Tirodker, U. H., Nataro, J. P., Smith, S., Las Casas, L. \& Fairchild, K. D. (2003). Detection of fungemia by polymerase chain reaction in critically ill neonates and children. J Perinatol 23, 117-122.

Wisplinghoff, H., Bischoff, T., Tallent, S. M., Seifert, H., Wenzel, R. P. \& Edmond, M. B. (2004). Nosocomial bloodstream infections in US hospitals: analysis of 24,179 cases from a prospective nationwide surveillance study. Clin Infect Dis 39, 309-317. 